\title{
Er svaret enda flere piller?
}

Det er enighet om at den økte risikoen som pasienter med høyt blodtrykk har, kan reduseres på to måter: livsstilsendringer og medikamentell behandling. Utover disse prinsippene har det vært livlige diskusjoner om hva som er den riktige behandlingen. Men nå ser vi at blodtrykksnivået i flere populasjoner er på vei nedover, og sykeligheten og dødeligheten av hjerte- og karsykdommene er stadig på retur (1). Er ikke det et godt og sikkert tegn på at blodtrykksbehandlingen er på rett vei?

I dette nummer av Tidsskriftet har Salvesen Blix og medarbeidere gitt en oversikt over hvordan salget av blodtrykkssenkende medikamenter har utviklet seg helt siden 1970-årene (2). Tidligere var bare grossistbaserte omsetningstall tilgjengelig, men etableringen av Reseptregisteret i 2004 har gitt oss langt bedre muligheter til å følge utviklingen. Fordi noen av de blodtrykkssenkende medikamentene også blir utskrevet for andre diagnoser enn hypertensjon, er diagnosen på blåreseptene særlig viktig. Det viste seg f.eks. at omtrent halvparten av betablokkerne ble forskrevet for andre diagnoser. Riktignok sier ikke salgstallene noe om hvor mye av de forskrevne medisinene pasientene faktisk inntar. Manglende pasientetterlevelse har vært velkjent $i$ lang tid, og det er vel ingen grunn til å anta at denne utfordringen er blitt mindre de siste årene. Det er altså flere svakheter ved en slik statistikk, men det er liten grunn til å tvile på at det har vært en formidabel økning i omsetningen av blodtrykkssenkende medikamenter - en firedobling siden 1970-årene.

Når en så stor andel av befolkningen bruker slike medikamenter, er det trolig fordi det i dag er lavere blodtrykksgrenser og lavere behandlingsmål enn tidligere. Kan det bety at legene oftere tyr til reseptblokken i stedet for legge arbeid i å oppnå livsstilsendringer hos pasientene? Dersom man skal oppnå livsstilsendringer, kreves det tid og tålmodighet, og resultatene av slik bred intervensjon mot flere faktorer er ikke alltid like målbare som selve blodtrykksverdiene. Mange fastleger har dessuten et hardt arbeidspress, og de økonomiske incentivene i fastlegeordningen stimulerer ikke til tidkrevende forsøk på livsstilsintervensjon (3). Skal man bruke antihypertensiver, er det ofte nødvendig med store doser og kombinasjoner av flere medikamenter. Dette øker naturlig nok risikoen for medikamentelle bivirkninger. En av de store utfordringene i dagens helsetjeneste er uheldige medikamentkombinasjoner og polyfarmasi, særlig hos eldre. Det er neppe tvil om at den høye andelen eldre som får utskrevet blodtrykkssenkende medikamenter bidrar til å øke dette problemet (4), særlig ettersom det ikke foreligger gode retningslinjer for hvordan man skal seponere medikamenter hos eldre.

Tidligere var de høye kostnadene et vesentlig moment i debatten om blodtrykksbehandlingen, noe som bl.a. førte til det omstridte tiazidvedtaket i Stortinget i 2004. Dette vedtaket illustrerte at politikerne var villige til å gå ganske langt $\mathrm{i}$ å styre den medisinske behandlingen, og det utløste en hissig debatt. Mens vedtaket ble opphevet i 2010, er det innført ordning med foretrukne legemidler for flere andre medikamentgrupper, bl.a. lipidsenkende medikamenter, og det er særlig interessant at kostnadene for hjerte- og kretsløpsmidler trolig av den grunn er gått ned til tross for at forbruket har gått opp (5). Slike regulerende tiltak ser altså ut til å ha effekt. Helsedirektoratet har nå også kommet med nye anbefalinger for å få ned saltforbruket i befolkningen (6), der det først og fremst satses på frivillig samarbeid med bl.a. matvareindustrien om redusert salttilsetning. Enkelte kan nok hevde at denne forhandlingslinjen overfor matvareindustrien er en fortsettelse av en tidligere strategi som ikke har vist effekt. Det er heller ikke registrert noen stor entusiasme omkring disse forslagene blant politikerne, matvareindustrien eller legene.

Risikoen for å sykeliggjøre friske mennesker har vært et viktig moment i debatten om blodtrykksbehandlingen. Det er påstått at bare et mindretall i befolkningen ville unnslippe behandling dersom legene faktisk skulle etterleve de internasjonale retningslinjene (7). Imidlertid er det indikasjoner på at legene i stor grad bruker sitt kliniske skjønn og overprøver retningslinjene og på den måten unngår å sykeliggjøre friske risikanter unødig (8). Når man tidligere vet at det er påvist betydelige kvalitetsutfordringer knyttet til både diagnostikk, behandling og oppfølging av denne pasientgruppen (9), kan det være grunn til å stille spørsmål ved den økte medikamentbruken. Selv om blodtrykket generelt har gått ned i flere populasjoner og hjerte- og karsykdommene er på retur, er det slett ikke sikkert at stadig økt omfang av medikamentell behandling er løsningen (10). I debatten omkring blodtrykksbehandlingen, der det også er betydelige økonomiske interesser involvert, er kampen om definisjonsmakten fortsatt sentral (11). Blant annet av den grunn er det viktig å følge utviklingen av medikamentforbruket også i årene fremover.

\section{Jostein Holmen}

jostein.holmen@ntnu.no

Jostein Holmen (f. 1947) er dr.med. og tidligere allmennlege. Han var tidligere leder for Helseundersøkelsen i Nord-Trøndelag (HUNT) og HUNT forskningssenter og er nå professor $\mathrm{i}$ anvendt samfunnsmedisin, HUNT forskningssenter, Institutt for samfunnsmedisin, Norges teknisknaturvitenskapelige universitet.

\section{Litteratur}

1. Statistics Norway. Cardiovascular mortality in Norway. Oslo: Statistisk sentralbyrå, 2011. www.ssb.no/histstat/tabeller/4-10-en.html (3.5.2012).

2. Blix HS, Landmark $K$, Selmer R et al. Forskrivning av antihypertensive legemidler 1975-2010. Tidsskr Nor Legeforen 2012; 132: 1224-8.

3. Kann IC, Biørn E, Lurås H. Competition in general practice: prescriptions to the elderly in a list patient system. J Health Econ 2010; 29: 751-64.

4. Brekke M, Rognstad S, Straand J et al. Pharmacologically inappropriate prescriptions for elderly patients in general practice: How common? Baseline data from The Prescription Peer Academic Detailing (Rx-PAD) study. Scand J Prim Health Care 2008; 26: 80-5.

5. Sakshaug SE. Legemiddelforbruket i Norge 2007-2011. Oslo: Nasjonalt folkehelseinstitutt, 2012

6. Helsedirektoratet. Strategi for å begrense saltinntaket i befolkningen. www. helsedirektoratet.no/folkehelse/ernering/strategier-og-satsninger/Sider/ saltstrategi.aspx (3.5.2012).

7. Westin S, Heath I. Thresholds for normal blood pressure and serum cholesterol. BMJ 2005; 330: 1461-2

8. Hetlevik I, Getz L, Kirkengen AL. Allmennleger som ikke følger retningslinjer kan de ha sine grunner? Tidsskr Nor Legeforen 2008; 128: 2218-20.

9. Hetlevik I, Holmen J, Krüger 0. Implementing clinical guidelines in the treatment of hypertension in general practice. Evaluation of patient outcome related to implementation of a computer-based clinical decision support system. Scand J Prim Health Care 1999; 17: 35-40.

10. Anand SS, Yusuf S. Stemming the global tsunami of cardiovascular disease. Lancet 2011; 377: 529-32.

11. Swensen E. red. Diagnose: Risiko. Oslo: Universitetsforlaget, 1999. 